\title{
Biological impact of the TSH $\beta$ splice variant in health and disease
}

\author{
John R. Klein* \\ Department of Diagnostic and Biomedical Sciences, University of Texas Health Science Center at Houston, Houston, TX, USA
}

\section{Edited by:}

Oreste Gualillo, Santiago University

Clinical Hospital, Spain

\section{Reviewed by:}

Lee Mosley, University of Nebraska

Medical Center, USA

Bellur S. Prabhakar, University of

Illinois at Chicago, USA

*Correspondence:

John R. Klein, Department of

Diagnostic and Biomedical Sciences,

School of Dentistry, University of

Texas Health Science Center at

Houston, 1941 East Road, Houston,

TX 77054, USA

e-mail: john.r.klein@uth.tmc.edu
Thyroid stimulating hormone (TSH), a glycoprotein hormone composed of $\alpha$ and $\beta$ chains, is produced by thyrotrope cells of the anterior pituitary. Within the conventional endocrine loop, pituitary-derived TSH binds to receptors in the thyroid, resulting in the release of the thyroid hormones thyroxine $\left(T_{4}\right)$ and triiodothyronine $\left(T_{3}\right) . T_{4}$ and $T_{3}$ in turn regulate nearly every aspect of mammalian physiology, including basal metabolism, growth and development, and mood and cognition. Although TSH $\beta$ has been known for years to be produced by cells of the immune system, the significance of that has remained largely unclear. Recently, a splice variant of TSH $\beta$ (TSH $\beta v$ ), which consists of a truncated but biologically functional portion of the native form of $\mathrm{TSH} \beta$, was shown to be produced by bone marrow cells and peripheral blood leukocytes, particularly cells of the myeloid/monocyte lineage. In contrast, full-length native TSH $\beta$ is minimally produced by cells of the immune system. The present article will describe the discovery of the TSH $\beta$ V and will discuss its potential role in immunity and autoimmunity, inflammation, and bone remodeling.

Keywords: alternatively spliced, bone marrow, hormone, immune-endocrine, isoform, pituitary, thyroid, thyrotropin

\section{TSH AND THE IMMUNE SYSTEM}

The hypothalamus-pituitary-thyroid (HPT) axis is an integrated hormone network that is essential for maintaining mammalian physiology, basal metabolism, growth, development, mood, and cognition. Thyroid stimulating hormone (TSH) belongs to a set of glycoprotein hormones that includes lutropin, follitropin, and chorionic gonadotropin. All four hormones consist of an $\alpha$-subunit and a non-covalently bound $\beta$-subunit (1). Hormone specificities are dictated by the $\beta$-subunit. Thyrotropin-releasing hormone (TRH) is produced in the hypothalamus and transported to the anterior pituitary via the superior hypophyseal artery, where it induces the release of TSH. TSH travels via the circulation to the thyroid, binds to the TSH receptor (TSHR) on thyroid follicular cells, and induces the secretion of the thyroid hormones, thyroxine $\left(\mathrm{T}_{4}\right)$ and triiodothyronine $\left(\mathrm{T}_{3}\right)$. Although $\mathrm{T}_{4}$ is the predominant thyroid hormone present in the circulation, it is principally a pro-hormone of more biologically active $\mathrm{T}_{3}$, which is generated following conversion of $\mathrm{T}_{4}$ to $\mathrm{T}_{3}$ in the tissues by deiodinases. Extensive feedback mechanisms, in particular the levels of circulating TSH, $\mathrm{T}_{4}$ and $\mathrm{T}_{3}$, control TRH and TSH output.

The mouse TSH $\beta$ gene consists of five exons. The human TSH $\beta$ gene consists of three exons. The coding regions are located in exons 4 and 5, and exons 2 and 3 , in mouse and human TSH $\beta$, respectively. There is considerable homology at both the gene and protein levels between human and mouse TSH $\beta$ (2). In both species, TSH $\beta$ consists of 138 amino acids, 118 of which comprise the native TSH $\beta$ protein with a 20 amino acid signal peptide. Evidence that TSH is produced by cells of the immune system dates back over three decades (3-5). Since then, TSH has been shown to have extensive involvement in immune regulation, development, and effector function activity in primary and secondary lymphoid cell populations, as well as in mucosal sites in the intestine.
A number of reviews have covered these topics (6-8). Additionally, an osteoprotective role for TSH has recently been reported in bone formation involving osteoblast generation and osteoclast destruction (9). The focus of the present review will be on the characterization and function of a recently described TSH $\beta$ splice variant (TSH $\beta v)$ (10).

\section{IDENTIFICATION AND CHARACTERIZATION OF THE TSH $\beta V$}

Although TSH can be produced by both myeloid and lymphoid cells, myeloid cells in the bone marrow (BM) and peripheral leukocytes generated from those cells are the primary source of immune system TSH $(6,11-13)$. Intracellular staining for TSH $\beta$ and quantification of TSH synthesis by enzyme-linked assays revealed a $\mathrm{CD}_{11 \mathrm{~b}^{+}}$cell population to be the predominant $\mathrm{BM}$ TSH $\beta$-producing cell (14).

An early clue that immune system TSH may have a functional role in regulating metabolism came from in vivo studies in which mice expressing a transgenic $\mathrm{T}$ cell receptor for henegg lysozyme had transient suppression of circulating $\mathrm{T}_{3}$ and $\mathrm{T}_{4}$, and that there was an influx of $\mathrm{CD} 11 \mathrm{c}^{+}$cells into the thyroid following antigen exposure (15). Moreover, hypophysectomized (HPX) mice challenged with alloantigen had a significant increase in serum $\mathrm{T}_{4}$ levels (15). Because HPX mice are unable to make pituitary-derived TSH, the signal responsible for elevated levels of $\mathrm{T}_{4}$ appeared to have been derived from an extrapituitary source.

Trafficking studies in which BM cells from enhanced green fluorescent protein transgenic mice were used to reconstitute lethally irradiated syngeneic host animals demonstrated the presence of intrathyroidal leukocytes consisting of $\mathrm{CD} 11 \mathrm{~b}^{+}$cells that did not express CD3, CD4, CD $8 \alpha, C D 19$, CD40, Ly-6G, or F4/80, although a small proportion were $\mathrm{CD} 11 \mathrm{c}^{+}(14)$. Trafficking to the thyroid occurred as early as 1 week post-BM reconstitution and continued 
until at least 20 weeks post-reconstitution (14). Direct evidence that intrathyroidal $\mathrm{CD}_{11} \mathrm{~b}^{+}$cells produced TSH was established by two-color staining of fresh-frozen thyroid tissue sections using anti-CD11b and anti-TSH $\beta$ antibodies (14).

While conducting a series of studies to assess the conditions under which TSH is produced in the thyroid, we observed that there was no amplification of the TSH $\beta$ gene in BM cells or

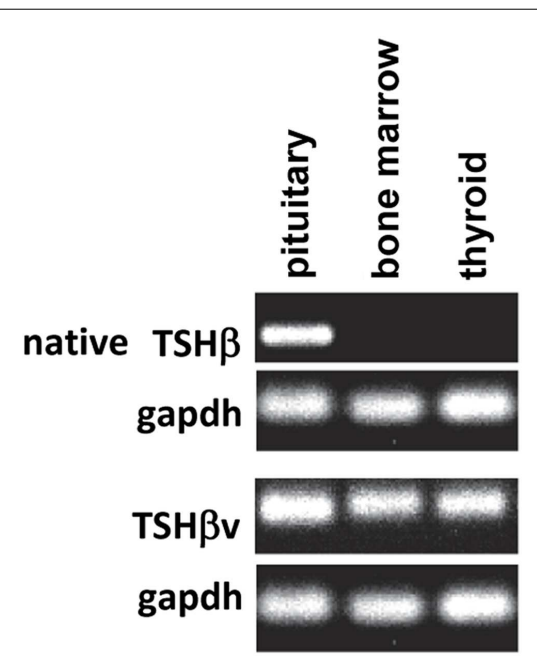

FIGURE 1 | PCR analysis of native TSH $\beta$ and TSH $\beta v$ gene expression in mouse pituitary, bone marrow, and thyroid tissues. Note the expression of the native form of TSH $\beta$ in the pituitary but not the bone marrow and thyroid, and the expression of the TSH $\beta$ in all three tissues. Presented data were derived from Ref. (10). thyroid tissues using primers targeted to the full-length mouse TSH $\beta$ transcript (all of exons 4 and 5) (10). Using a primer set that targeted the $3^{\prime}$ end of intron 4 and a downstream region just after the TAA stop codon of exon 5, conventional and qRT-PCR analyses were done from pituitary, thyroid, and BM tissues. A PCR product was detectable in the pituitary but not the BM or thyroid using primers for the full-length native transcript, whereas a PCR product was detected in the pituitary, the BM, and the thyroid using primers that targeted exon 5 (Figure 1). This suggested that alternative splicing of the TSH $\beta$ gene had occurred at or near the beginning of mouse exon 5, thus excluding exon 4 from the gene product. DNA sequencing of the PCR product revealed homology to exon 5 of the mouse TSH $\beta$ gene with a portion of intron 4 that was retained and contiguous with exon 5 (10). This consisted of 27 nucleotides from intron 4 beginning with an ATG start codon and was in-frame with exon 5 of mouse TSH $\beta$. This coded for nine amino acids (MLRSLFFPQ) and a truncated protein comprising $71 \%$ of the native TSH $\beta$ molecule (10). Similar findings were obtained using human tissues (16). These are shown in Figure 2. However, the possibility also must be considered that transcription of $\mathrm{TSH} \beta \mathrm{v}$ is due not to alternative splicing but to initiation of transcription from within introns 4 and 2 of mouse and human TSH $\beta$, respectively.

Studies using the mouse T $\alpha \mathrm{T} 1$ thyrotropic cell line and the mouse AM macrophage cell line demonstrated high levels of native TSH $\beta$ and minimal TSH $\beta v$ in T $\alpha \mathrm{T} 1$ cells, and low levels of native TSH $\beta$ and high levels of TSH $\beta v$ in AM cells (Figure 3). Mouse BMderived myeloid cells have been shown to preferentially express the $\mathrm{TSH} \beta \mathrm{v}$ in $\mathrm{CD} 11 \mathrm{~b}^{+} \mathrm{M} 2$ macrophages relative to $\mathrm{M} 1$ macrophages (17). Expression of the TSH $\beta \mathrm{v}$ is low in monocytes, neutrophils, and lymphocytes (17).

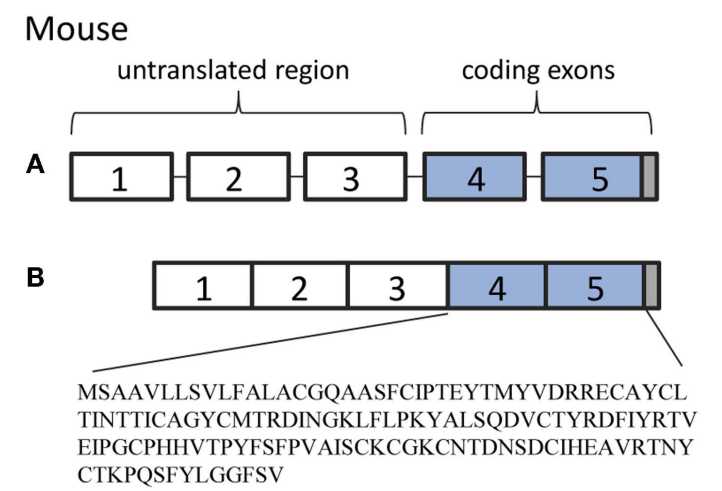

C

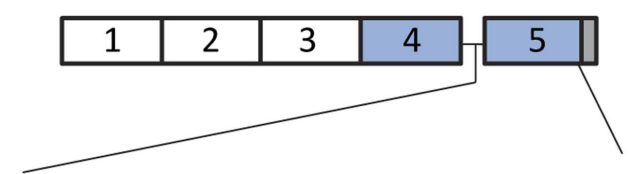

MLRSLFFPQDINGKLFLPKYALSQDVCTYRDFIYRTVEIPGC PHHVTPYFSFPVAISCKCGKCNTDNSDCIHEAVRTNYCTKP QSFYLGGFSV
Human

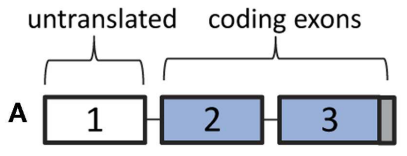

B

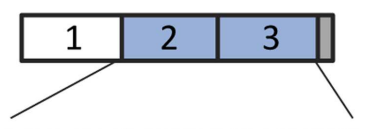

MTALFLMSMLFGLTCGQAMSFCI PTEYTMHIERRECAYCLTINTTIC AGYCMTRDINGKLFLPKYALSQD VCTYRDFIYRTVEIPGCPLHVAPY FSYPVALSCKCGKCNTDYSDCIH EAIKTNYCTKPQKSYLVGFSV

C

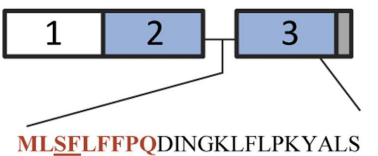
QDVCTYRDFIYRTVEIPGCPLHVA PYFSYPVALSCKCGKCNTDYSDC IHEAIKTNYCTKPQKSYLVGFSV
FIGURE 2 | (A) Genetic organization of the mouse and human TSH $\beta$ gene. (B) The native TSH $\beta$ polypeptide in mice and humans is coded for by exons 4 and 5, and exons 2 and 3, respectively (blue boxes). (C) The $\mathrm{TSH} \beta \mathrm{v}$ polypeptide is coded for by exon 5 in mice and exon 3 in humans. The 27 nucleotide $3^{\prime}$ end of intron 4 in mouse and intron 2 in human TSH $\beta$ v codes for a nine amino acid signal peptide (shown in red) beginning with a methionine translational start site. Gray boxes represent stop codons. 


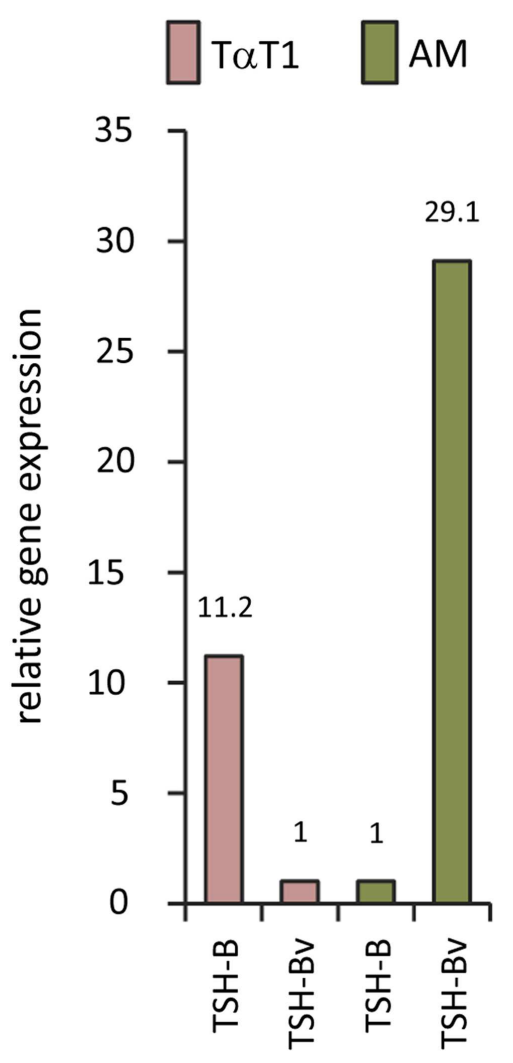

FIGURE 3 | Gene expression of native TSH $\beta$ and TSH $\beta v$ in mouse T $\alpha$ T1 thyrotropic cells and the mouse AM macrophage cell line, showing low $\mathrm{TSH} \beta \mathrm{v}$ gene expression in $\mathrm{T} \alpha \mathrm{T} 1$ cells and high expression in macrophages.

In mice, the TSH $\beta v$ transcript is present in tissues throughout the body, whereas the full-length native TSH $\beta$ transcript is largely restricted to the pituitary (Figure 4). The wide distribution of the TSH $\beta \mathrm{v}$ isoform likely does not reflect expression by the somatic tissues themselves, but may represent the presence of leukocytes, particularly $\mathrm{CD}_{11} \mathrm{~b}^{+}$cells within the circulation, that are embedded in those tissues, although this has yet to be formally demonstrated. The presence of trace amounts of native TSH $\beta$ gene expression in the lung is interesting but unclear at this time.

Evidence that the TSH $\beta v$ protein is actively secreted comes from western blot studies using supernatants from $\mathrm{CHO}$ cells transfected with the mouse TSH $\beta \mathrm{v}$ gene (10), from western blots of serum from healthy persons (18), and from mass spectrometry analysis of peptides from BM cell culture supernatants (17). Co-immunoprecipitation experiments using recombinant human $\mathrm{TSH} \alpha$ and TSH $\beta \mathrm{v}$ revealed dimerization of the TSH $\beta \mathrm{v}$ with TSH $\alpha$ (18), a condition that would be needed for optimal binding of the TSH $\beta \mathrm{v}$ to the TSHR.

\section{ROLE OF THE TSH $\beta v$ IN HEALTH AND DISEASE \\ TSH $\beta v$ DURING ANTIGENIC CHALLENGE AND VIRUS INFECTION}

That the TSH $\beta$ v retains functional activity in terms of intracellular signaling has been established from in vitro studies of cAMP responses in mouse AM cells and rat FRTL thyroid follicular cells

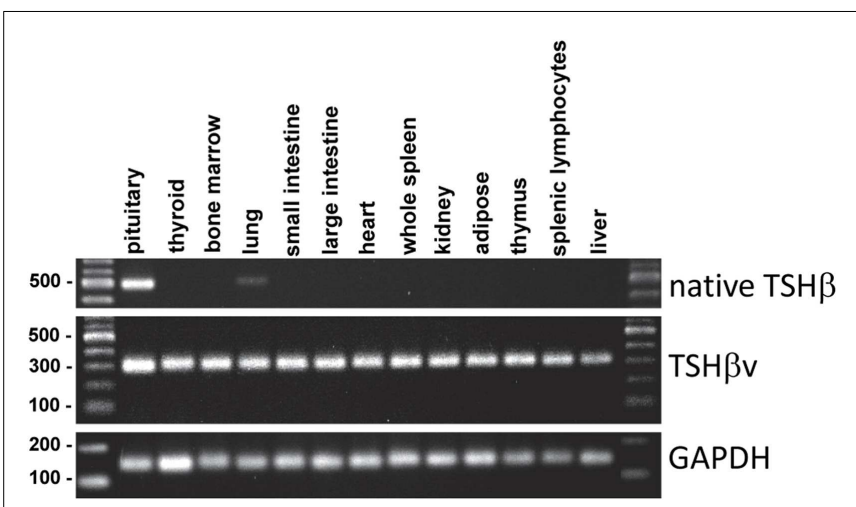

FIGURE 4 | Tissue distribution of native TSH $\beta$ and TSH $\beta v$ in 13 mouse tissues. Note the restricted expression of native TSH $\beta$ primarily in the pituitary, and the wide distribution of $\mathrm{TSH} \beta v$ throughout the other tissues.

(10), and in Chinese hamster ovary cells transfected with the TSHR cultured in the presence of BM macrophages as a source of TSH $\beta v$ (17).

To determine if antigenic challenge, in this case virus infection, influences the expression levels of the TSH $\beta \mathrm{v}$ in the thyroid, C57BL/6 mice were infected intraperitoneally with serotype 3 reovirus. Thyroid tissues were isolated $48 \mathrm{~h}$ later. Virus infection had no effect on native TSH $\beta$ gene expression in the thyroid relative that of non-infected mice; however, there was a significant increase in TSH $\beta v$ transcript levels in the thyroid of virus-infected mice (10) (Figure 5), indicating that the host response to infection was accompanied by a selective increase in intrathyroidal synthesis of the TSH $\beta v$. These findings, coupled with studies using alloantigen-primed mice (15), suggest that elevated levels of the $\mathrm{TSH} \beta \mathrm{v}$ are produced in the thyroid during foreign antigen exposure. The effect of this may be to suppress circulating thyroid hormone production and lower the host metabolic activity during periods of infection by blocking native TSH $\beta$ binding. A model for this has been proposed (19). Interestingly, TSH $\beta$ synthesis also has been shown to be increased in the small intestine of mice following oral infection with reovirus (20) or rotavirus (21), although the form of TSH $\beta$ produced locally was not determined in those studies.

\section{TSHBv IN CHRONIC INFLAMMATION}

Besides the involvement of immune system TSH during infection, there are a large number of human conditions with links to thyroid dysregulation that have yet to be fully understood, many of which have notable inflammatory components. These include Graves' disease and Hashimoto's thyroiditis (22), Graves' ophthalmopathy $(23,24)$, Pendred's syndrome (25), Lyme disease (26), inflammatory bowel disease (27), rheumatoid arthritis (28), systemic lupus erythematosus $(29,30)$, psoriasis (31), asthma (32), sepsis $(33,34)$, and hypothyroidism that may accompany type I interferon therapy (35-37).

Although much still needs to be done to establish a role for $\mathrm{TSH} \beta \mathrm{v}$ in disease, some evidence for this already exists. In a study of patients with Hashimoto's thyroiditis (HT), transcript levels of the TSH $\beta \mathrm{v}$ were higher in peripheral blood leukocytes (PBL) 


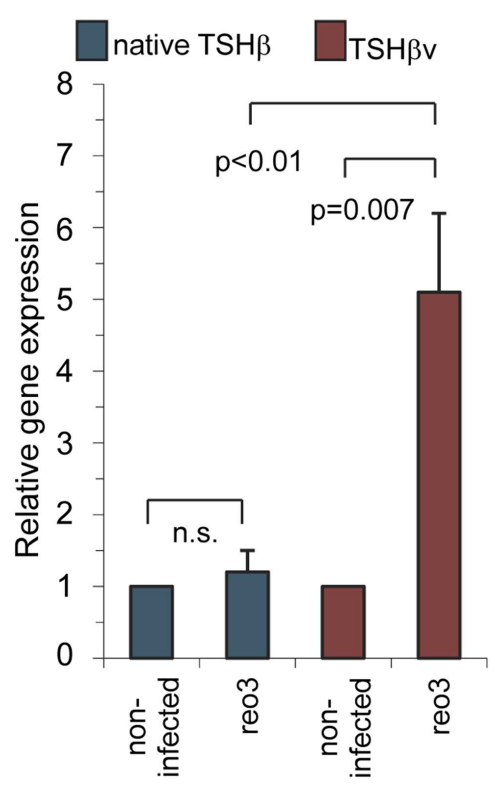

FIGURE 5 | Systemic reovirus infection induces gene expression of $\mathbf{T S H} \beta \mathbf{v}$ but not native TSH $\beta$ in thyroid tissues. Mice were infected intraperitoneally with $10^{7.5}$ plaque-forming units of reovirus serotype 3 Dearing strain. Tissues were assayed for gene expression $48 \mathrm{~h}$ post-infection. Presented data were derived from Ref. (10).

of HT patients compared to normal controls (18). Prednisone treatment of HT patients significantly reduced TSH $\beta \mathrm{v}$ transcript levels in patients having a short duration of disease ( $\leq 9$ months) compared to patients with a long duration ( $\geq 18$ months) or to controls. Consistent with that, TSH $\beta v$ transcript levels in PBL of HT patients were reduced in a dose-dependent manner in vitro upon exposure to dexamethasone (18). These findings point to a potential involvement of the TSH $\beta \mathrm{v}$ in the pathogenesis of HT.

\section{TSH $\beta v$ AS A REGULATOR OF BONE MORPHOGENESIS}

Recent studies have identified an osteoprotective role for TSH involving osteoclast growth and osteoclast inhibition (9). Although early studies linking bone loss and thyroid function were largely regarded to be due to elevated thyroid hormone levels, studies using $T s h r^{-1-}$ mice that were incapable of delivering a TSHR signal but were made hyperthyroid by $\mathrm{T}_{4}$ supplementation revealed a pattern of bone loss similar to that of hyperthyroid wildtype mice, thus implicating a failure of TSH signaling, not excessive thyroid hormone synthesis, as the cause of poor bone remodeling (38). Those findings now have been linked to the TSH $\beta \mathrm{v}$ as shown by the proximity of TSH $\beta \mathrm{v}$-producing macrophages in mouse vertebral bone, by the capacity of macrophage-derived TSH $\beta \mathrm{v}$ to induce osteoblast formation, and suppression in the presence of anti-TSH antibody (17).

\section{POTENTIAL CLINICAL INVOLVEMENT OF THE TSH $\beta v$ IN HEALTH AND DISEASE}

The TSH $\beta \mathrm{v}$ - the first functional alternatively spliced form of TSH $\beta$ to be identified in mice and humans $(10,16,39)-$ could have a multitude of here-to-fore unknown biological activities, which may be beneficial or detrimental to the host depending upon the clinical setting. Already, three potential candidates for this have been identified.

First, the TSH $\beta$ v may contribute to the process by which thyroid hormone synthesis is regulated. Competitive binding of TSH $\beta \mathrm{v}$ to thyroid TSHR may block native TSH $\beta$ binding. Whether this occurs, or whether the TSH $\beta$ v can preferentially displace native $\mathrm{TSH} \beta$ or vice-verse, has yet to be demonstrated. Similarly, it will be of interest to determine the extent to which TSH $\beta \mathrm{v}$ and native TSH $\beta$ bind to discrete regions of the TSHR, and whether they differentially dimerize to the TSH $\alpha$ moiety. Competitive binding studies may help to elucidate this. Additionally, the fact that the TSHR is widely expressed in the BM and throughout the peripheral immune system $(13,21,40-42)$, raises questions of whether those cells operate in some manner to regulate the amount of immune system-derived TSH $\beta v$ that is available. Preliminary studies in our laboratory using recombinant mouse TSH $\beta$ v suggest this leads to lower circulating $\mathrm{T}_{4}$ levels (Montufar-Solis and Klein, unpublished). Whether that effect is beneficial to the host remains to be determined; however, during acute infection, immune system-derived TSH $\beta \mathrm{v}$ may function as an alternative regulator of metabolism.

Second, continually dysregulated synthesis of TSH $\beta v$ from cells of the immune system, possibly as a consequence of chronic inflammation due to the excessive accumulation of $\mathrm{CD}_{11} \mathrm{~b}^{+}$cells, could lead to HT. The TSH $\beta$ v protein, which was shown to be present in sera of normal persons (18), may increase in chronic inflammatory conditions, resulting in a non-homeostatic tilt favoring the TSH $\beta v$ isoform over native TSH $\beta$. This was implied by the finding of increased gene expression levels of TSH $\beta \mathrm{v}$ in PBL of HT patients (18). Interestingly, hypothyroidism is an occasional complication of patients undergoing type I interferon therapy (3537). Whether that reflects an imbalance between native $\operatorname{TSH} \beta$ and $\mathrm{TSH} \beta \mathrm{v}$ caused by an inflammatory response induced by interferon is unknown. Further studies will need to be done to address this.

Third, the beneficial effects of TSH $\beta \mathrm{v}$ produced by boneassociated M2 macrophages could be an on-going process throughout life linked to bone remodeling (17). This would provide a local source of TSH that could be modulated independently of pituitary TSH. Whether the numbers, or the production of the $\mathrm{TSH} \beta \mathrm{v}$, of BM-derived macrophages is changed during aging will be of interest to determine.

Clearly, a key feature of the TSH $\beta \mathrm{v}$ isoform is its immune system source. This provides a new and exciting insight into how two of the body's major physiological systems, the immune system and the endocrine system, come together in a collaborative way in the maintenance of health, and in the potential for disease when disruption of that axis occurs.

\section{ACKNOWLEDGMENTS}

The author thanks Jeremy Schaefer and Dina Montufar-Solis for review of the manuscript and helpful discussions. This work was supported in part by NIH grants DK035566 and AI100159.

\section{REFERENCES}

1. Szkudlinski MW, Fremont V, Ronin C, Weintraub BD. Thyroid-stimulating hormone and thyroid-stimulating hormone receptor structure-function relationships. Physiol Rev (2002) 82(2):473-502. doi:10.1152/physrev.00031.2001 
2. Gordon DF, Wood WM, Ridgway EC. Organization and nucleotide sequence of the gene encoding the beta-subunit of murine thyrotropin. DNA (1988) 7(1):17-26. doi:10.1089/dna.1988.7.17

3. Smith EM, Phan M, Kruger TE, Coppenhaver DH, Blalock JE. Human lymphocyte production of immunoreactive thyrotropin. Proc Natl Acad Sci U S A (1983) 80(19):6010-3. doi:10.1073/pnas.80.19.6010

4. Kruger TE, Blalock JE. Cellular requirements for thyrotropin enhancement of in vitro antibody production. J Immunol (1986) 137(1):197-200.

5. Harbour DV, Kruger TE, Coppenhaver D, Smith EM, Meyer WJ III. Differential expression and regulation of thyrotropin (TSH) in T cell lines. Mol Cell Endocrinol (1989) 64(2):229-41. doi:10.1016/0303-7207(89)90150-0

6. Wang HC, Klein JR. Immune function of thyroid stimulating hormone and receptor. Crit Rev Immunol (2001) 21 (4):323-37. doi:10.1615/CritRevImmunol. v21.i4.20

7. Harvey S, Aramburo C, Sanders EJ. Extrapituitary production of anterior pituitary hormones: an overview. Endocrine (2012) 41(1):19-30. doi:10.1007/ s12020-011-9557-z

8. Quintanar JL, Guzman-Soto I. Hypothalamic neurohormones and immune responses. Front Integr Neurosci (2013) 7:56. doi:10.3389/fnint.2013.00056

9. Zaidi M, Davies TF, Zallone A, Blair HC, Iqbal J, Moonga SS, et al. Thyroidstimulating hormone, thyroid hormones, and bone loss. Curr Osteoporos Rep (2009) 7(2):47-52. doi:10.1007/s11914-009-0009-0

10. Vincent BH, Montufar-Solis D, Teng BB, Amendt BA, Schaefer J, Klein JR. Bone marrow cells produce a novel TSH $\beta$ splice variant that is upregulated in the thyroid following systemic virus infection. Genes Immun (2009) 10(1):18-26. doi:10.1038/gene.2008.69

11. Wang J, Whetsell M, Klein JR. Local hormone networks and intestinal T cell homeostasis. Science (1997) 275(5308):1937-9. doi:10.1126/science.275.5308. 1937

12. Whetsell M, Bagriacik EU, Seetharamaiah GS, Prabhakar BS, Klein JR. Neuroendocrine-induced synthesis of bone marrow-derived cytokines with inflammatory immunomodulating properties. Cell Immunol (1999) 192(2):159-66. doi:10.1006/cimm.1998.1444

13. Wang HC, Dragoo J, Zhou Q, Klein JR. An intrinsic thyrotropin-mediated pathway of TNF-alpha production by bone marrow cells. Blood (2003) 101(1):119-23. doi:10.1182/blood-2002-02-0544

14. Klein JR, Wang HC. Characterization of a novel set of resident intrathyroidal bone marrow-derived hematopoietic cells: potential for immune-endocrine interactions in thyroid homeostasis. J Exp Biol (2004) 207(Pt 1):55-65. doi: 10.1242/jeb.00710

15. Bagriacik EU, Zhou Q, Wang HC, Klein JR. Rapid and transient reduction in circulating thyroid hormones following systemic antigen priming: implications for functional collaboration between dendritic cells and thyroid. Cell Immunol (2001) 212(2):92-100. doi:10.1006/cimm.2001.1846

16. Schaefer JS, Klein JR. A novel thyroid stimulating hormone $\beta$-subunit isoform in human pituitary, peripheral blood leukocytes, and thyroid. Gen Comp Endocrinol (2009) 162(3):241-4. doi:10.1016/j.ygcen.2009.04.006

17. Baliram R, Chow A, Huber AK, Collier L, Ali MR, Morshed SA, et al. Thyroid and bone: macrophage-derived TSH-beta splice variant increases murine osteoblastogenesis. Endocrinology (2013) 154(12):4919-26. doi:10.1210/en.2012-2234

18. Liu C, Li L, Ying F, Xu C, Zang X, Gao Z. A newly identified TSHbeta splice variant is involved in the pathology of Hashimoto's thyroiditis. Mol Biol Rep (2012) 39(12):10019-30. doi:10.1007/s11033-012-1871-x

19. Schaefer JS, Klein JR. Immunological regulation of metabolism - a novel quintessential role for the immune system in health and disease. FASEB J (2011) 25(1):29-34. doi:10.1096/fj.10-168203

20. Varghese S, Montufar-Solis D, Vincent BH, Klein JR. Virus infection activates thyroid stimulating hormone synthesis in intestinal epithelial cells. J Cell Biochem (2008) 105(1):271-6. doi:10.1002/jcb.21825

21. Scofield VL, Montufar-Solis D, Cheng E, Estes MK, Klein JR. Intestinal TSH production is localized in crypt enterocytes and in villus 'hotblocks' and is coupled to IL-7 production: evidence for involvement of TSH during acute enteric virus infection. Immunol Lett (2005) 99(1):36-44. doi:10.1016/j.imlet.2004.12.010

22. Salmaso C, Bagnasco M, Pesce G, Montagna P, Brizzolara R, Altrinetti V, et al. Regulation of apoptosis in endocrine autoimmunity: insights from Hashimoto's thyroiditis and Graves' disease. Ann N Y Acad Sci (2002) 966:496-501. doi:10. 1111/j.1749-6632.2002.tb04253.x

23. Mooij P, Drexhage HA. Interactions between the immune system and the thyroid. Regulatory networks in health and disease. Thyroidology (1992) 4(1):45-8.
24. Douglas RS, Afifiyan NF, Hwang CJ, Chong K, Haider U, Richards P, et al. Increased generation of fibrocytes in thyroid-associated ophthalmopathy. J Clin Endocrinol Metab (2010) 95(1):430-8. doi:10.1210/jc.2009-1614

25. Camargo R, Limbert E, Gillam M, Henriques MM, Fernandes C, Catarino AL, et al. Aggressive metastatic follicular thyroid carcinoma with anaplastic transformation arising from a long-standing goiter in a patient with Pendred's syndrome. Thyroid (2001) 11(10):981-8. doi:10.1089/105072501753211073

26. Vaccaro M, Guarneri F, Borgia F, Cannavo SP, Benvenga S. Association of lichen sclerosus and autoimmune thyroiditis: possible role of Borrelia burgdorferi? Thyroid (2002) 12(12):1147-8. doi:10.1089/105072502321085261

27. Bianchi GP, Marchesini G, Gueli C, Zoli M. Thyroid involvement in patients with active inflammatory bowel diseases. Ital J Gastroenterol (1995) 27(6):291-5.

28. Maksymowych WP, Brown MA. Genetics of ankylosing spondylitis and rheumatoid arthritis: where are we at currently, and how do they compare? Clin Exp Rheumatol (2009) 27(4 Suppl 55):S20-5.

29. Parente Costa L, Bonfa E, Martinago CD, de Oliveira RM, Carvalho JF, Pereira RM. Juvenile onset systemic lupus erythematosus thyroid dysfunction: a subgroup with mild disease? J Autoimmun (2009) 33(2):121-4. doi:10.1016/j.jaut. 2009.04.001

30. Mader R, Mishail S, Adawi M, Lavi I, Luboshitzky R. Thyroid dysfunction in patients with systemic lupus erythematosus (SLE): relation to disease activity. Clin Rheumatol (2007) 26(11):1891-4. doi:10.1007/s10067-007-0602-5

31. Gul U, Gonul M, Kaya I, Aslan E. Autoimmune thyroid disorders in patients with psoriasis. Eur J Dermatol (2009) 19(3):221-3. doi:10.1684/ejd. 2009.0632

32. Manzolli S, Macedo-Soares MF, Vianna EO, Sannomiya P. Allergic airway inflammation in hypothyroid rats. J Allergy Clin Immunol (1999) 104(3 Pt 1):595-600. doi:10.1016/S0091-6749(99)70329-5

33. Collins J, Gough S. Autoimmunity in thyroid disease. Eur J Nucl Med Mol Imaging (2002) 29(Suppl 2):S417-24. doi:10.1007/s00259-002-0848-8

34. Lodha R, Vivekanandhan S, Sarthi M, Arun S, Kabra SK. Thyroid function in children with sepsis and septic shock. Acta Paediatr (2007) 96(3):406-9. doi:10.1111/j.1651-2227.2007.00135.x

35. Monzani F, Caraccio N, Dardano A, Ferrannini E. Thyroid autoimmunity and dysfunction associated with type I interferon therapy. Clin Exp Med (2004) 3(4):199-210. doi:10.1007/s10238-004-0026-3

36. Carella C, Mazziotti G, Morisco F, Manganella G, Rotondi M, Tuccillo C, et al. Long-term outcome of interferon-alpha-induced thyroid autoimmunity and prognostic influence of thyroid autoantibody pattern at the end of treatment. J Clin Endocrinol Metab (2001) 86(5):1925-9. doi:10.1210/jc.86.5.1925

37. Tomer Y, Blackard JT, Akeno N. Interferon alpha treatment and thyroid dysfunction. Endocrinol Metab Clin North Am (2007) 36(4):1051-66. doi:10.1016/j.ecl. 2007.07.001

38. Baliram R, Sun L, Cao J, Li J, Latif R, Huber AK, et al. Hyperthyroid-associated osteoporosis is exacerbated by the loss of TSH signaling. J Clin Invest (2012) 122(10):3737-41. doi:10.1172/JCI63948

39. Wang SH, Koenig RJ. A locally secreted thyrotropin variant may regulate thyroid function in thyroid inflammatory disorders. Thyroid (2009) 19(1):5-6. doi:10.1089/thy.2008.1564

40. Kruger TE, Smith LR, Harbour DV, Blalock JE. Thyrotropin: an endogenous regulator of the in vitro immune response. J Immunol (1989) 142(3): 744-7.

41. Coutelier JP, Kehrl JH, Bellur SS, Kohn LD, Notkins AL, Prabhakar BS. Binding and functional effects of thyroid stimulating hormone on human immune cells. J Clin Immunol (1990) 10(4):204-10. doi:10.1007/BF00918653

42. Bagriacik EU, Klein JR. The thyrotropin (thyroid-stimulating hormone) receptor is expressed on murine dendritic cells and on a subset of CD45RBhigh lymph node T cells: functional role for thyroid-stimulating hormone during immune activation. J Immunol (2000) 164(12):6158-65.

Conflict of Interest Statement: The author declares that the research was conducted in the absence of any commercial or financial relationships that could be construed as a potential conflict of interest.

Received: 23 January 2014; paper pending published: 05 March 2014; accepted: 24 March 2014; published online: 07 April 2014.

Citation: Klein JR (2014) Biological impact of the TSH $\beta$ splice variant in health and disease. Front. Immunol. 5:155. doi: 10.3389/fimmu.2014.00155 
This article was submitted to Inflammation, a section of the journal Frontiers in Immunology.

Copyright $(2014$ Klein. This is an open-access article distributed under the terms of the Creative Commons Attribution License (CC BY). The use, distribution or reproduction in other forums is permitted, provided the original author(s) or licensor are credited and that the original publication in this journal is cited, in accordance with accepted academic practice. No use, distribution or reproduction is permitted which does not comply with these terms. 